\title{
Pengembangan Media Kit Pembelajaran untuk Siswa Kelas III Sekolah Dasar terhadap Materi Pecahan Sederhana
}

\author{
${ }^{1)}$ Fita Ayu Apriyasha, ${ }^{2)}$ Taufik Hidayat, dan ${ }^{3)}$ Nareswari Anita \\ ${ }^{1,2,3)}$ Universitas Indraprasta PGRI
}

\section{INFO ARTICLES}

\section{Article History:}

Received: 6-Juni-2019

Revised: 15-Juni-2019

Approved: 26-Juni-2019

Publish Online: 29-Juni-2019

\section{Key Words:}

Media, Pembelajaran, Puzzle, Pecahan

\section{(c) () (2)}

\begin{abstract}
The research purpose is to produce media learning so that students more easily understand basic concepts of fractions, and provide a sense of love for the students. Development of instructional design used in this study refers to the learning system design model ADDIE (Analysis, Design Develop Implement Evaluate) mixed according to the steps in the development of research recommendations by Borg and Gall on the basis of the consideration that the model suitable for the instructional model product mngembangkan ADDIE (Analysis, Design Develop Implement Evaluate). Puzzle Fractions learning media made so that help students understand the basic concept of fractions and provide a sense of happy students to realize the creation of learning in accordance with the provisions of The Curriculum of 2013
\end{abstract}

\begin{abstract}
Abstrak: Tujuan penelitian ini untuk menghasilkan media pembelajaran sehingga siswa lebih mudah memahami konsep dasar pecahan dan memberikan rasa senang bagi siswa. Pengembangan desain pembelajaran yang digunakan dalam penelitian ini mengacu pada model desain sistem pembelajaran $A D D I E$ (Analysis Design Develop Implement Evaluate) yang dipadukan menurut langkah-langkah penelitian pengembangan yang di rekomendasi oleh Borg dan Gall dengan dasar pertimbangan bahwa model tersebut cocok untuk mngembangkan produk model instruksional ADDIE (Analysis Desain Develop Implement Evaluate). Media pembelajaran Puzzle Pecahan dibuat sehingga membantu siswa memahami konsep dasar pecahan dan memberikan rasa senang siswa untuk mewujudkan terciptanya pembelajaran yang sesuai dengan ketentuan Kurikulum 2013
\end{abstract}

Correspondence Address: Jl. Raya Tengah, Kel. Gedong, Pasar Rebo, Jakarta Timur, 13760; e-mail: fitaayuapriyasha7@gmail.com

How to Cite (APA $6^{\text {th }}$ Style): Apriyasha, Hidayat, \& Anita. (2019). Pengembangan Media Kit Pembelajaran untuk Siswa Kelas III Sekolah Dasar terhadap Materi Pecahan Sederhana. JKPM (Jurnal Kajian Pendidikan Matematika), Vol 4 (2): 163-172.

Copyright: Apriyasha, F. A., dkk. (2019)

Competing Interests Disclosures: The authors declare that they have no significant competing financial, professional or personal interests that might have influenced the performance or presentation of the work described in this manuscript. 


\section{PENDAHULUAN}

Salah satu diantara masalah besar dalam bidang pendidikan di Indonesia yang perlu diperhatikan dan mendapatkan penanganan yang tepat adalah rendahnya pemahaman siswa terhadap materi yang sedang dipelajari, khususnya siswa Sekolah Dasar (SD). Matematika merupakan salah satu mata pelajaran yang diajarkan pada setiap jenjang pendidikan di Indonesia mulai dari Sekolah Dasar (SD) sampai dengan Sekolah Menengah Atas (SMA) menurut Tatik Hartini (2007:3) dalam "Hubungan Antara Minat Siswa Belajar Matematika dan Kebiasaan Belajar Matematika dengan Prestasi Belajar Matematika", diperoleh fakta yang menunjukan kurangnya minat siswa untuk belajar matematika karena kebiasaan belajar siswa yang salah sehingga membuat pelajaran matematika menjadi membosankan. Padahal sukses dalam belajar matematika adalah muara dari semua kegiatan yang dilakukan oleh siswa dalam proses pembelajaran matematika. Hal ini termuat dalam Mulyatna dan Nofiansyah (2018), "Success in learning mathematics is the estuary of all activities carried out by students in the learning process of mathematics."

Menurut jurnal yang dituliskan oleh Umar Wirantasa, "Banyak diantara siswa yang tidak memahami tentang pentingnya matematika. Ketidakpahaman siswa disebabkan kurangnya renungan tentang fungsi matematika itu sendiri. Padahal kalau siswa mau sedikit merenung mengenai pentingan matematika maka banyak sekali fungsi matematika dalam kehidupan sehari-hari. Ketika siswa tersebut berangkat sekolah dengan menggunakan atau menaiki angkutan umum, maka ketika siswa turun dari angkutan tersebut ia akan membayar dengan sejumlah uang kepada supir angkutan tersebut. Kegiatan membayar uang tersebut adalah termasuk fungsi matematika. Selain itu dalam melaksanakan kegiatan sehari-hari kita tidak bisa jauh atau tanpa melihat sebuah waktu di jam. Kalau siswa mau mengamati jam tersebut maka terdapat angka-angka dari satu sampai dua belas, angka-angka tersebut juga termasuk fungsi matematika. Sebenarnya masih banyak sekali fungsi matematika. Oleh sebab itu matematika sangat penting dalam berbagai aspek kehidupan.".

Menurut hasil survei kami dengan cara menyebarkan angket kepada guru kelas III Sekolah Dasar, Menyatakan bahwa kondisi siswa kelas III Sekolah Dasar di tempatnya mengajar saat ini masih kurang memahami materi pecahan dengan cukup baik, yang mana siswa sulit memahami jika dijelaskan teorinya secara lisan saja tanpa dibantu dengan media pembelajaran. Rendahnya pemahaman siswa terdahap materi pecahan dapat dibuktikan dengan hasil evaluasi belajar siswa pada materi pecahan. Hasil evaluasi belajar siswa menunjukan nilai siswa di bawah rata-rata kriteria ketuntasan minimal (KKM)

Menurut survei yang telah dilakukan kepada guru kelas III tingkat Sekolah Dasar, siswa membutuhkan hal lain selain teori dan contoh soal untuk membantu mereka dalam memahami materi pecahan. Guru kelas III tingkat Sekolah Dasar memilih menggunakan media kit sebagai media alat bantu mengajar kepada siswa. Dengan adanya media kit, siswa menjadi lebih mengerti konsep materi yang sedang dipelajari daripada mempelajari materi tanpa media alat bantu. Karena media kit merupakan alat yang memiliki fisik yang dapat digunakan oleh siswa, bukan hanya sekedar angka-angka dalam soal-soal latihan yang biasanya diberikan oleh guru dalam proses kegiatan belajar dan mengajar.

Tujuan dari penelitian ini adalah untuk mengenalkan media yang kami buat dengan harapan media tersebut dapat membantu siswa agar memahami konsep dasar pecahan. Kami lakukan sebagai usaha sadar dan terencana untuk dapat memberikan kesenangan siswa dan untuk mewujudkan terciptanya pembelajaran yang sesuai dengan ketentuan Kurikulum 2013. 


\section{METODE}

Jenis penelitian yang digunakan dalam penelitian ini adalah penelitian pengembangan (Research and Development). Menurut Sugiyono (2011:297) metode penelitian yang digunakan untuk menghasilkan produk tertentu, dan menguji keefektifan produk tersebut. Produk yang dihasilkan dalam penelitian ini adalah media pembelajaran berbasis Kit Alat Peraga. Penelitian mengembangkan produk media pembelajaran matematika berbasis Kit Alat Peraga dengan materi himpunan untuk siswa SMP kelas III. Produk tersebut divalidasi oleh ahli materi, dinilai oleh guru matematika dari siswa SD kelas III.

Model analisis yang digunakan dalam analisis kebutuhan ini dengan menggunakan tahapan pertama (analisis) pada model pengembangan ADDIE, yaitu model pengembangan yang terdiri dari lima tahapan yang meliputi analisis (analysis), desain (design), pengembangan (development), implementasi (implementation), dan evaluasi (evaluation). Model pengembangan ADDIE dikembangkan oleh Dick and Carry pada tahun 1996 untuk merancang sistem pembelajaran (Mulyatiningsih, 2011).

Tujuan dari fase analisis adalah untuk mengidentifikasi kemungkinan penyebab dari kesenjangan kinerja (Branch, 2009), prosedur analisis kebutuhan pada Project Base Learning dapat dilihat pada Gambar. 1:

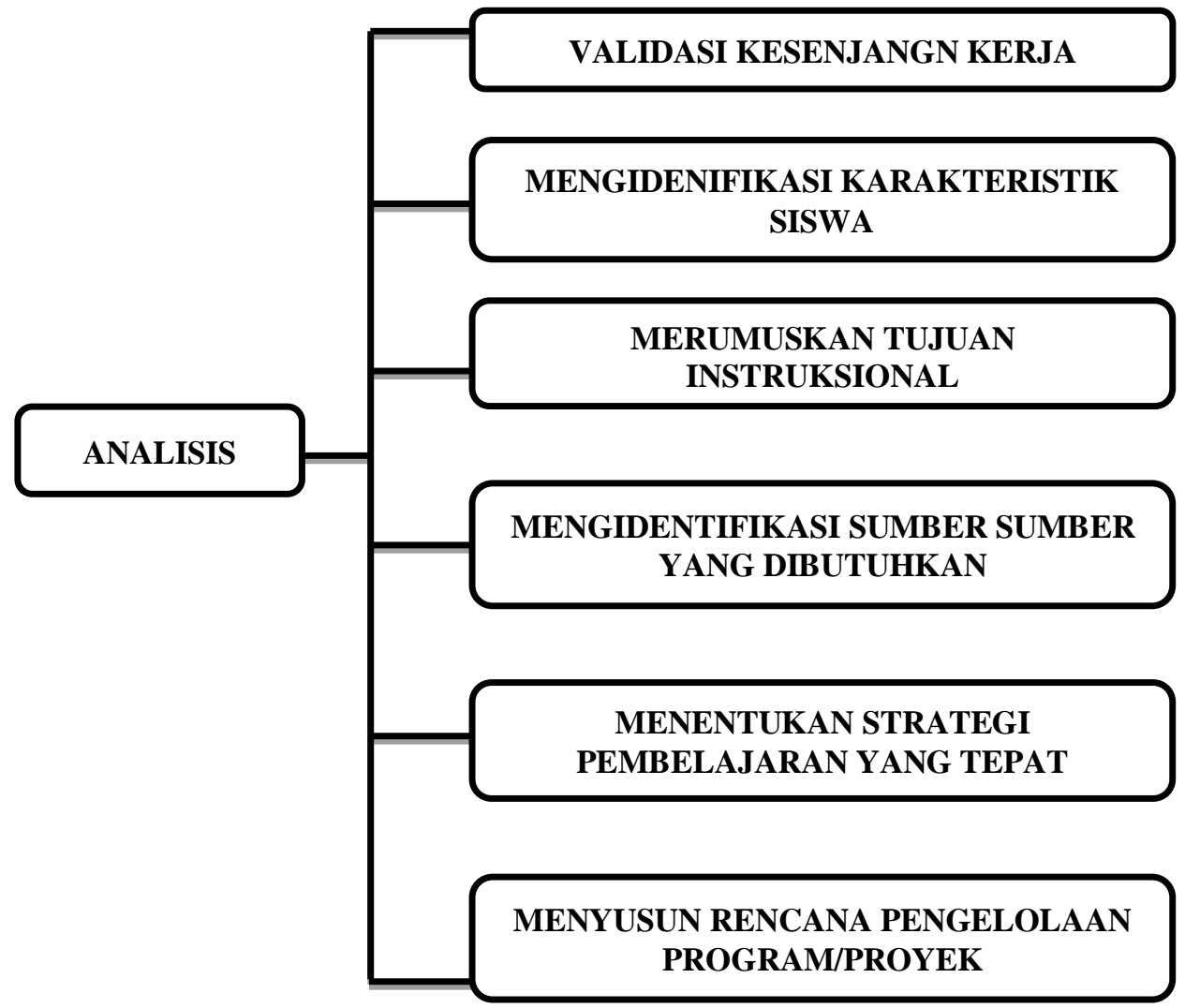

\section{Gambar 1. Prosedur Analisis Kebutuhan}

Teknik pengumpulan data pada penelitian ini adalah menggunakan angket atau kuesioner. Angket ini digunakan untuk mengetahui bentuk media, materi dan pembahasan matematika serta alur cerita yang akan di kembangkan. Hasil angket ini yang menjadi penugasan pembelajaran mahasiswa pada Project Base Learning yang dilakukan. 


\section{HASIL}

\section{Hasil Analisis Kebutuhan 1: Validasi Kesenjangan Kinerja}

Pada analisis ini dilakukan dengan menggunakan instrumen angket kebutuhan media pembelajaran dengan responden guru Sekolah Dasar. Pada analisis dengan responden guru, ada 3 responden guru SD di wilayah Bekasi dan Depok dengan ringkasan hasil angket dapat dilihat pada Tabel 1.

\section{Tabel 1. Hasil Angket Kebutuhan Media Pembelajaran}

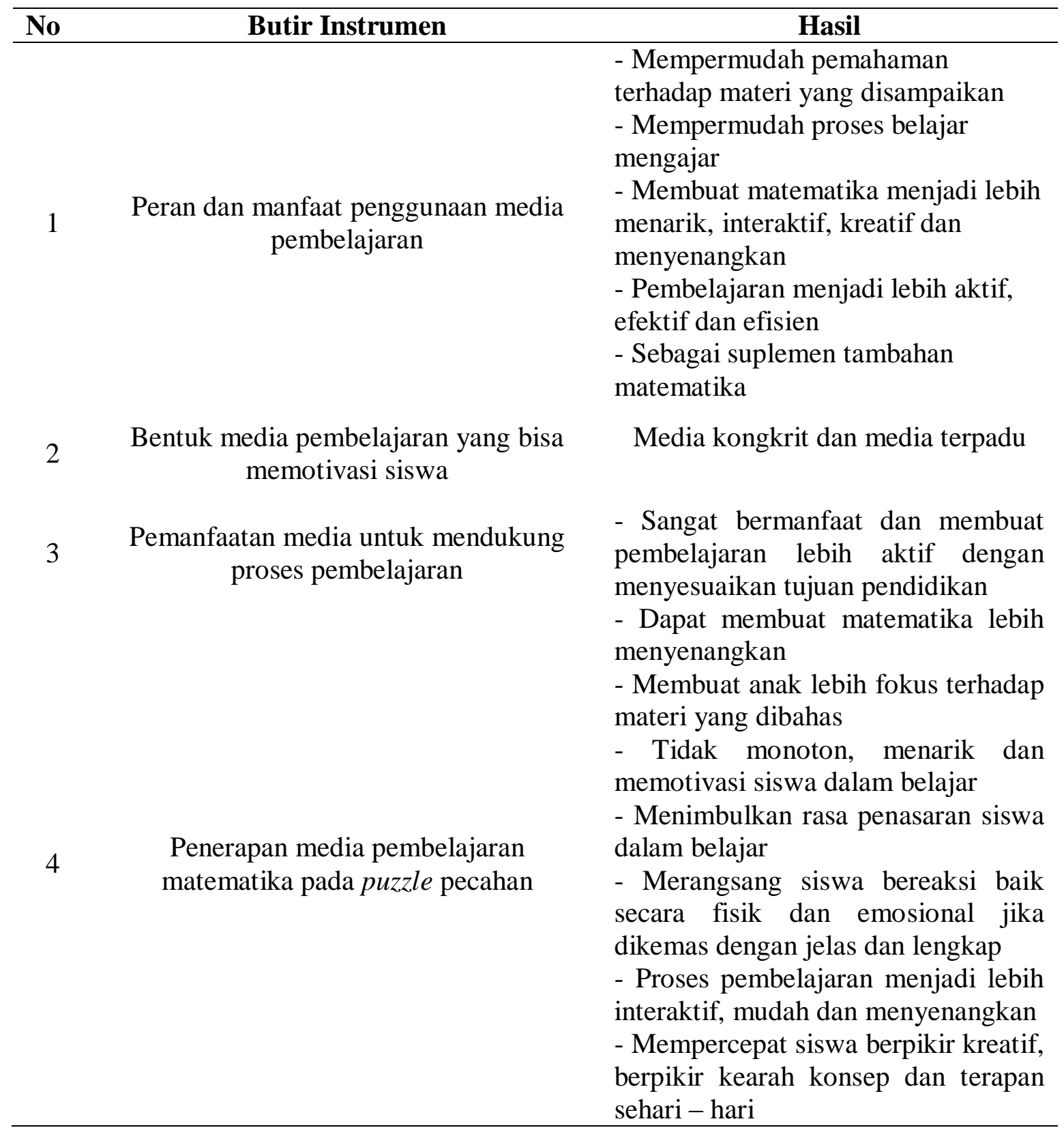




\section{Hasil Analisis Kebutuhan 2: Mengidentifikasi Karakteristik Siswa}

Analisis karakter siswa juga dilakukan dengan menggunakan angket dengan bentuk pilihan ganda. Respondennya terdiri dari 3 siswa Sekolah Dasar kelas rendah di wilayah Bekasi, ada tiga kelompok variabel yang digunakan yaitu terdiri dari minat siswa terhadap pelajaran matematika, pengetahuan siswa tentang bahasan matematika dan bentuk media belajar yang disukai.

Pada hasil minat siswa terhadap pelajaran matematika, terdapat 35\% siswa berpendapat belajar matmatika menggunakan gambar lebih mudah dipahami, 40\% siswa menyukai matematika dengan menggunakan media dan bentuk yang menarik. 25\% siswa menyukai matematika karena simulasi atau penjelasan yang diberikan. Adapun pada bentuk media belajar yang disukai siswa dapat dilihat pada Gambar 2.

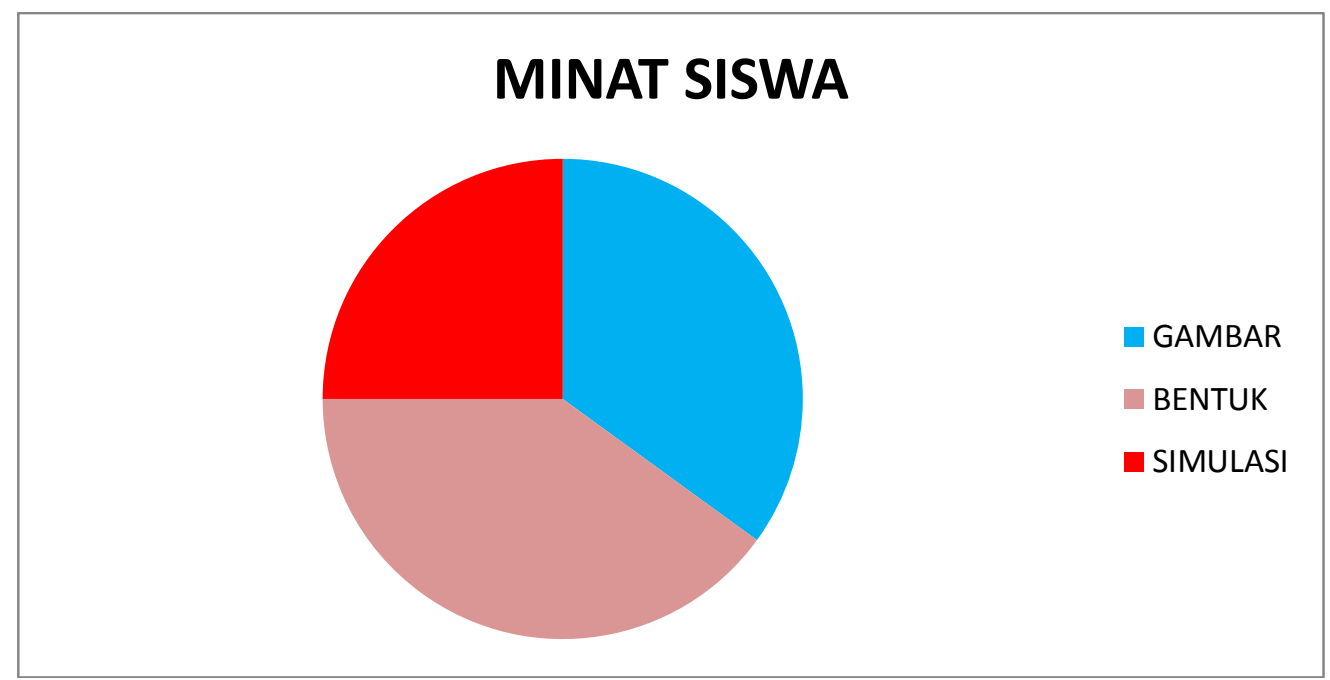

Gambar 2. Diagram yang Menunjukan Minat Siwa

\section{Hasil Analisis Kebutuhan 3: Merumuskan Tujuan Instruksional}

Tujuan instruksional dari pembuatan media pembelajaran ini dirumuskan dengan menganalisis Rencana Pembelajaran Semester Workshop Matematika Dasar dan melihat kesenjangan kinerja yang dilakukan pada analisis kebutuhan 1 maka dirumuskan tujuan instruksional adalah mahasiswa dapat membuat media pembelajaran matematika SD berbasis media pembelajaran dengan baik, benar dan menarik serta disukai $80 \%$ responden. Oleh karena itu mahasiswa harus mempresentasikan produk yang telah dibuat kepada panelis dari mahasiswa dan dosen.

\section{Hasil Analisis kebutuhan 4 : Mengidentifikasi Sumber - Sumber yang Dibutuhkan}

Tahapan ini merupakan tahapan inventaris kebutuhan perkakas, kayu, dan styrofoam. Perkakas yang dipakai sebagai alat bantu pembuatan media pembelajaran. Beberapa perkakas yang digunakan adalah palu, gergji, paku, cutter, engsel, lem, pensil, dan penggaris. Materi bahasan dan penentuan judul dengan menggunakan bahan ajar pada KI/KD Sekolah Dasar kelas rendah.

\section{Hasil Analisis kebutuhan 5: Menentukan Strategi Pembelajaran}

Strategi pembelajaran yang dilakukan adalah menggunakan strategi pembelajaran berbasis ADDIE, yaitu model pengembangan yang terdiri dari lima tahapan yang meliputi analisis (analysis), desain (design), pengembangan (development), implementasi (implementation), dan evaluasi (evaluation). Model 
pengembangan ADDIE dikembangkan oleh Dick and Carry pada tahun 1996 untuk merancang sistem pembelajaran.

Proyek mahasiswa ini bertajuk pengembangan media pembelajaran matematika dengan membuat puzzle pecahan. Waktu yang dibutuhkan untuk mahasiswa menyelesaikan Project ADDIE ini adalah selama empat bulan efektif (satu semester) di semester ganjil tahun akademik 2018/2019 dengan tingkat kesulitan cukup tinggi. Pelaksanaan monitoring kepada mahasiswa dilakukan perminggu selama 2 sks efektif.

Kriteria penilaian yang digunakan adalah dengan melihat hasil produk dari PBL dan penilaian kerjasama antar anggota kelompok mahasiswa. Hasil produk dinilai dengan melihat kesesuaian antara penjelasan matematika pada film animasinya dengan konsep matematika yang dibahas, menarik tidaknya film tersebut untuk siswa Sekolah Dasar kelas rendah dan kemampuan komunikasi film animasi matematika dengan siswa.

\section{Hasil Analisis Kebutuhan 6: Menyusun Rencana Pengelolaan Program/Proyek}

Penyusunan rencana pengelolaan dilakukan dengan membuat penjadwalan dengan tujuan menjaga agar proyek dapat terselesaikan secara baik dengan menggunakan waktu yang efektif. Rencana pengelolaan program melalui empat tahap, yaitu tahap persiapan meliputi pengenalan pembuatan media pembelajaran berbasis kit. Tahap kedua menyusun materi ajar. Tahap ketiga adalah memproduksi media kit dan tahap keempat adalah memberikan sentuhan akhir produk, mempresentasikan hasil proyek dan penilaian produk mahasiswa.

\section{PEMBAHASAN}

Pada analisis kesenjangan kinerja menunjukkan minat dan kebutuhan guru akan media pembelajaran cukup tinggi, terutama melihat kebutuhan siswa kelas 3 Sekolah Dasar. Oleh karena itu, media pembelajaran sangat dibutuhkan pada mata pelajaran matematika, materi matematika akan sulit jika hanya dijelaskan secara verbal saja. Dari hasil angket kesenjangan kinerja dapat dilihat bahwa media pembelajaran yang diminati adalah media pembelajaran media pembelajaran bantu berupa fisik, interaktif dan menyenangkan, tetapi media ini jarang didaparkan di masyarakat. Media pembelajaran berupa kit merupakan alat bantu dalam rangka memperoleh pengalaman belajar secara signifikan. menurut Nanang Hanafiah, (2009) dapat diperoleh melalui: situasi dan kondisi yang sesungguhnya, mengamati benda pengganti dalam wujud alat peraga,membaca bahan-bahan cetakan, seperti majalah, buku, surat kabar dan sebagainya.Dalam tahap implementasi kegiatan, penyajian yang dilakukan melalui tindakan dimana murid secara langsung terlibat dalam memanipulasi (mengotak-atik) objek. Pada tahap ini anak belajar sesuatu pengetahuan dimana pengetahuan itu dipelajari secara aktif, dengan menggunakan benda-benda konkret atau menggunakan situasi yang nyata.

Pada tahapan mengidentifikasi karakter siswa dari data terlihat bahwa sebenernya siswa sekolah dasar memiliki minat yang baik terhadap pelajaran matematika, hanya saja bahasa matematika yang abstrak ini perlu untuk disampaikan dengan menggunakan metode dan media pembelajaran yang tepat sehingga penyampaian materi matematika dituntut untuk sesuai dengan tahapan perkembangan anak. Menurut Piaget dalam Hasbullah dan Wiratomo (2015) Pada tahap operasional konkret (7-11 tahun), seorang anak dapat membuat kesimpulan dari sesuatu pada situasi nyata atau dengan menggunakan benda konkret, dan mampu mempertimbangkan dua aspek dari situasi nyata secara bersama-sama (misalnya, antara bentuk dan ukuran). Usia SD kelas 3 dan 4 merupakan usia permulaan siswa pada kelompok usia kelas atas, berdasarkan hasil pengamatan maka pada usia ini anak memiliki ciri ciri diantaranya memiliki rasa ingin tahu dan belajar yang tinggi, suka membentuk kelompok sepermainan, suka dengan permainan, 
belum memiliki kesadaran tanggung jawab yang tinggi serta untuk anak yang tertentu senang dengan permainan.

Pada tahapan merumuskan tujuan instruksional, setelah menganalisis dari Rencana Pembelajaran, penyusunan tujuan instruksional ini menggunakan kaidah ABCD (Audience, Behaviour, Condition, Degree). Hasbullah dan Wiratomo (2015) mendefinisikan sebagai berikut: Audience adalah siswa yang akan belajar, behavior adalah perilaku spesifik yang akan dimunculkan oleh siswa setelah selesai proses belajarnya dalam pelajaran tersebut, condition adalah kondisi atau batasan yang dikenakan kepada siswa atau alat yang digunakan siswa pada saat di tes (bukan pada saat belajar), dan degree adalah tingkat keberhasilan siswa dalam mencapai perilaku tersebut. Rumusan tujuan instruksional juga merujuk kepada identifikasi karakter siswa seperti minat, karakter dan kemampuan mahasiswa serta sejauh mana kemampuan dan kreatifitas yang telah dimiliki oleh siswa.

Adapun tujuan instruksional dalam pembuatan media pembelajaran berbasis kit. Tujuan instruksional dapat dirumuskan dengan menggunakan analisis kesenjangan kinerja disertai dengan analisis KI/KD. Pada langkah ini contoh dan uji coba yang dilakukan pada pembelajaran kepada mahasiswa adalah dengan menganalisis KI/KD matematika SD kelas 3 Kurikulum 2013 materi pecahan. Analisis ini memberikan penjabaran kompetensi dasar yang ada, merumuskan tujuan Instruksional dan menyusun uraian peta kompetensi, dan penjelasan dari masing-masing kompetensi sebagai berikut: Memahami konsep pecahan sederhana menggunakan benda-benda yang konkrit/gambar, serta menentukan nilai terkecil dan terbesar.

Kompetensi tersebut dibuat untuk menyusun rumusan tujuan instruksional yaitu siswa kelas 3 SD mampu memahami dan menyelesaikan soal matematika bahasan bilangan pecahan dengan benar $80 \%$.

Pada tahapan mengidentifikasi sumber-sumber yang dibutuhkan, untuk memudahkan proses pembuatan media, ditentukan alat dan bahan yang mudah didapat dan digunakan, yaitu kayu reng, triplek, styrofoam, dan lain-lain. Pemilihan alat dan bahan ini dipilih karena mudah didapat dan berbiaya murah. Tampilan Stop Motion Studio seperti terlihat pada Gambar 3.

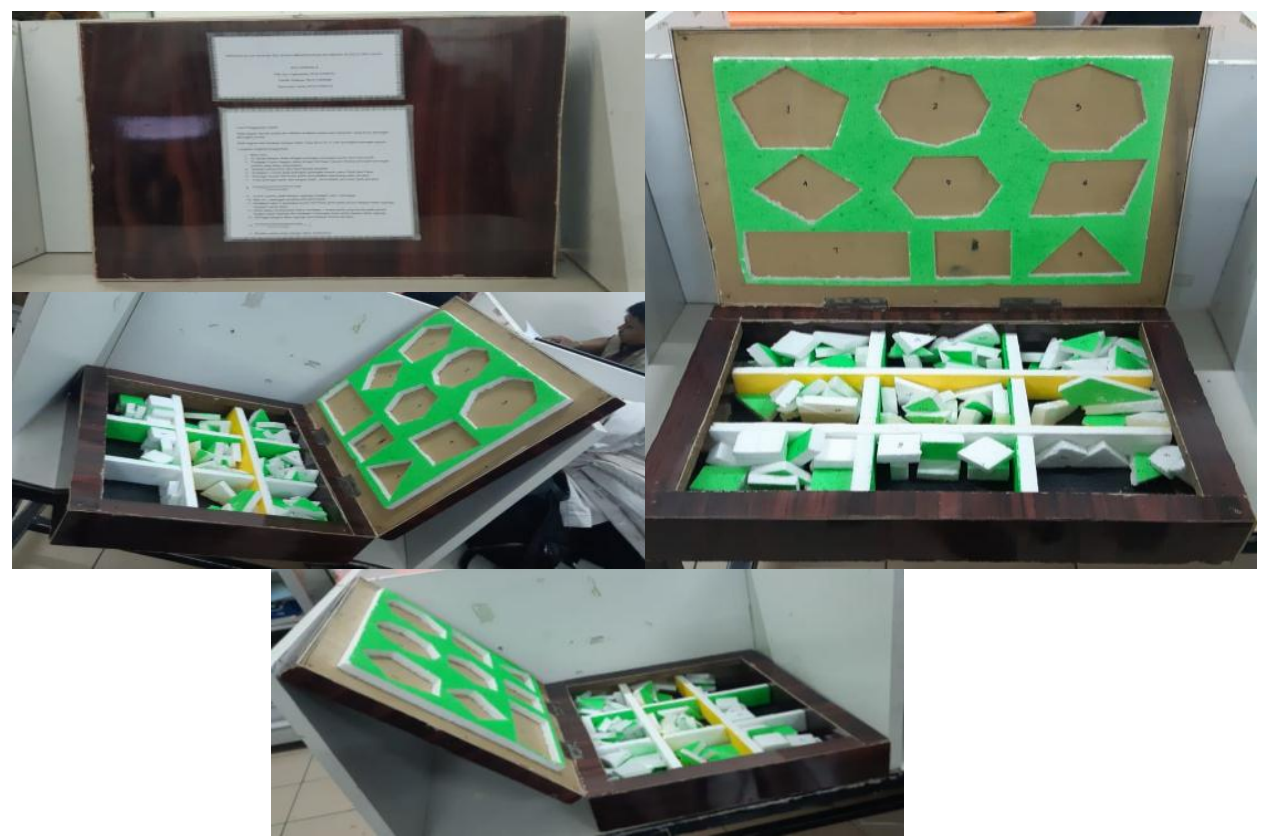

Gambar 3. Tampilan Media Kit Puzzle Pecahan 
Cara penggunaan media: pada bagian bawah ketika box dibuka terdapat tempat penyimpanan yang berisi potongan potongan puzzle.Pada bagian atas terdapat bangun datar yang harus diisi oleh potonganpotongan puzzle.

Langkah-langkah penggunaan

1. Buka box

2. Isi setiap bangun datar dengan potongan-potongan puzzle berwarna putih

3. Terdapat 9 jenis bangun datar dengan berbagai macam bentuk potongan-potongan puzzle yang harus disesuaikan

4. Setelah semua terisi lalu buat bentuk pecahan

5. Terdapat 2 warna pada potongan-potongan puzzle yakni Putih dan Hijau

6. Potongan puzzle berwarna putih menyatakan pembilang pada pecahan

7. Total potongan pada tiap bangun datar menyatakan penyebut pada pecahan

8. $\frac{\text { Potongan puzzle berwarna Putih }}{\text { Total potongan }}$

9. Ambil contoh, pada bangun segitiga terdapat total 3 potongan

10. Saat ini 3 potongan tersebut berwarna putih

11. Misalkan tukar 2 potongan puzzle berwarna putih pada puzzle bangun datar segitiga, menjadi warna hijau

12. Maka dapat disimpulkan bahwa terdapat 1 warna putih yang tersisa pada puzzle bangun datar segitiga dan terdapat 3 potongan total untuk bangun datar segitiga

13. Sehingga bangun datar segitiga menyatakan bentuk pecahan

14. $\frac{\text { Potongan puzzle berwarna Putih }}{\text { Total potongan }}=\frac{1}{3}$

15. Berlaku untuk setiap bangun datar selanjutnya

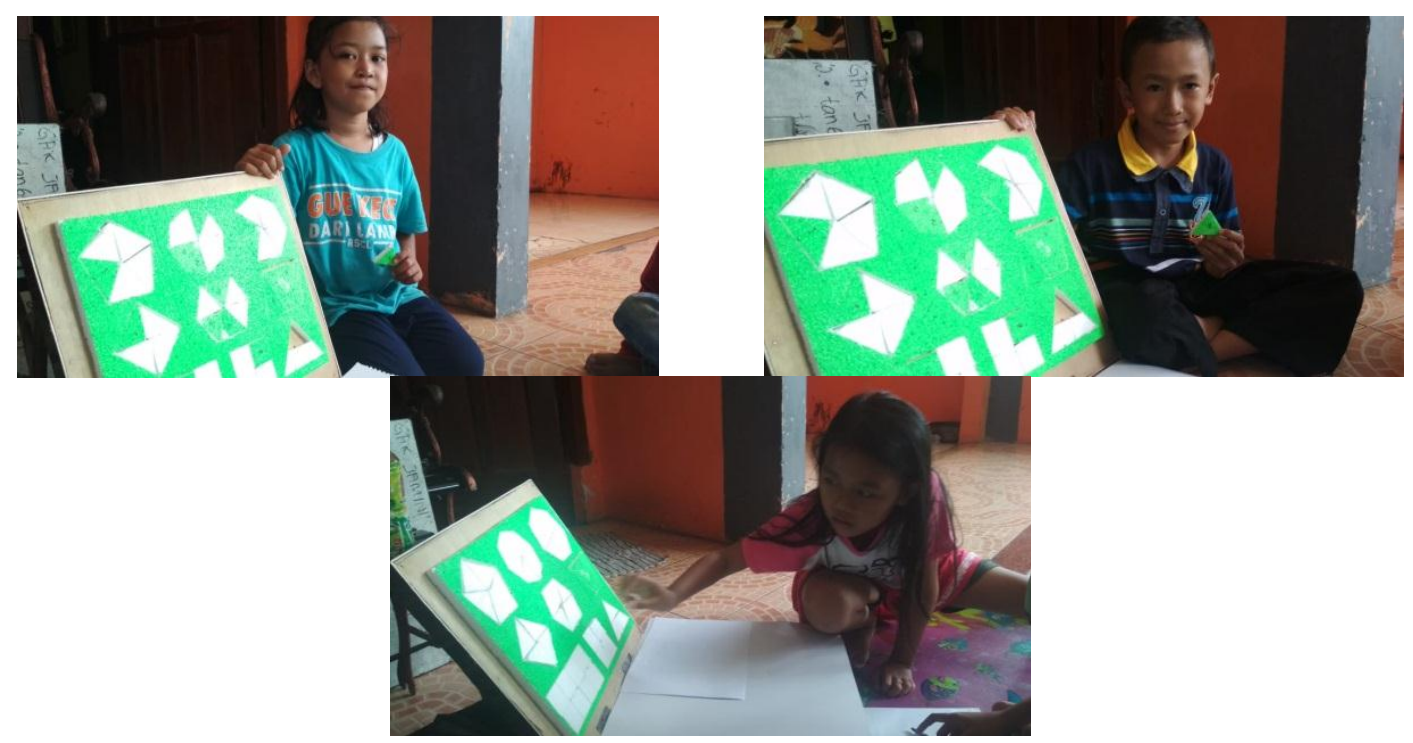

Gambar 4. Tampilan Siswa Menggunakan Media Kit Puzzle Pecahan 
Pengembangan media pembelajaran bagi peneliti selanjutnya hendaknya dapat diarahkan pada produk yang memanfaatkan perangkat lunak. Hal ini dimaksudkan agar dapat mengikuti perkembangan pada era revolusi industri 4.0. Seperti halnya penelitian yang dilakukan Komariah, Suhendri, \& Hakim (2018), media pembelajaran yang dikembangkan berupa aplikasi yang berbasis android.

\section{SIMPULAN}

Media pembelajaran Puzzle Pecahan dibuat dengan harapan media tersebut dapat membantu siswa agar memahami konsep dasar pecahan. Kami lakukan sebagai usaha sadar dan terencana untuk dapat memberikan kesenangan siswa dan utuk mewujudkan terciptanya pembelajaran yang sesuai dengan ketentuan Kurikulum 2013. Dari hasil analisis didapatkan bahwa proyek pembuatan media pembelajaran matematika berbasis media kit untuk Sekolah Dasar sangat layak untuk di buat sebagai alat belajar bagi siswa kelas 3 Sekolah Dasar. Pemilihan media pembelajaran matematika berbasis media kit ini memiliki manfaat yang sangat besar bagi siswa sehingga siswa dapat lebih mudah memahami konsep pelajaran matematika khususnya pada materi pengenalan konsep dasar pecahan.

\section{PENGHARGAAN}

Ucapan terimakasih saya ucapkan kepada Prodi Pendidikan Matematika, rekan-rekan mahasiswa dan dosen yang bersedia membimbing saya hingga penelitian ini selesai.

\section{DAFTAR RUJUKAN}

Ardiyansah, A. (2012). Film Animasi sebagai Medium Dokumentasi Kekayaan Alam, Intelektual, Budaya, dan Dinamika Sosial Politik. Humaniora, 3(2): 668-677. https://doi.org/10.21512/humaniora.v3i2.3411.

Bell, S. (2010). Project-based learning for the 21st century: Skills for the future. The Clearing House, 83(2), 39-43. https://doi.org/10.1080/00098650903505415.

Branch, R. M. (2009). Instructional design: The ADDIE approach. New York: Springer

Eliza, R. (2010). Media pembelajaran sebagai sarana komunikasi matematika di Sekolah Dasar. Ta'dib : Jurnal Pendidikan Islam, 13(2): 152-160.

Fauziyah, L., \& Jailani, J. (2014). Pengembangan perangkat pembelajaran matematika yang menunjang pendidikan karakter siswa kelas IV sekolah dasar. Jurnal Prima Edukasia, 2(2), 149-163. http://dx.doi.org/10.21831/jpe.v2i2.2715.

Gülbahar, Y., \& Tinmaz, H. (2006). Implementing project-based learning and e-portfolio assessment in an undergraduate course. Journal of Research on Technology in Education, 38(3), 309-327. https://doi.org/10.1080/15391523.2006.10782462

Hasanah, U., \& Nulhakim, L. (2015). Pengembangan media pembelajaran film animasi sebagai media pembelajaran konsep fotosintesis. Jurnal Penelitian dan Pembelajaran IPA, 1(1), 91-106. http://dx.doi.org/10.30870/jppi.v1i1.283

Hasbullah \& Wiratomo, Y. (2015). Metode, Model, Dan Pengembangan Model Pembelajaran Matematika. Jakarta: Unindra Press 
Komariah, S., Suhendri, H., \& Hakim, A.R. (2018). Pengembangan media pembelajaran matematika siswa SMP berbasis Android. JKPM (Jurnal Kajian Pendidikan Matematika), 4(1), 43-52

Mulyatiningsih, E. (2011). Metode Penelitian Terapan Bidang Pendidikan. Bandung: Alfabeta.

Mulyatna, F., \& Nofiansyah, W. (2019). Error patterns in determining combined probability functions from continuous random variables. Journal of Physics: Conf. Series, 1188(1)

Sadiman, A. (2002). Media Pendidikan. Jakarta: Raja Grafindo Persada. 